\title{
Spur gear design, manufacturing and noise analysis according to rolling method using complex numbers
}

\author{
Kompleks sayılar kullanılarak yuvarlanma yöntemine göre düz dişli tasarımı, imalatı ve \\ gürültü analizi
}

\author{
Mehmet YAZAR*1,a, Mithat YANIKÖREN ${ }^{2, b}$ \\ ${ }^{1}$ Çanakkale Onsekiz Mart University, Çanakkale Vocational School of Technical Sciences, Machinery and Metal \\ Technologies Department, 17020, Çanakkale \\ ${ }^{2}$ Bilecik Şeyh Edebali University, Bilecik Vocational School of Technical Sciences, Control and Automation Technology Department, \\ 11000, Bilecik
}

• Geliş tarihi / Received: 05.01.2021 • • Düzeltilerek geliş tarihi / Received in revised form: 07.10.2021 • Kabul tarihi / Accepted: 27.10 .2021

\begin{abstract}
In this study, a software has been improved for parametric drawing and modeling of spur gear using complex numbers in the CAD setting. AutoLISP programming language was used in software development. In the system, parameters such as module and number of teeth can be entered by the user and drawing or modeling of the gears in the CAD environment can be done automatically. This study provides the designer with fast and functional and more precise utility alternative for gear drawing and modeling. In addition, within the scope of the study, the same number of teeth and at the module spur gear were designed in the AutoCAD package program with the classical method. Spur gears, designed in AutoCAD program with the developed package program and classical method, were produced on the wire EDM machine by deriving cutting codes in the MasterCAM program. Noise analysis of the produced spur gear pairs has been made. It was determined that the spur gear pair, designed and produced with the package program developed within the scope of the study, operates approximately $8 \mathrm{~dB}$ less noise than the spur gear designed and produced with the classical method. It is possible to design and manufacture the gear in the desired profile by changing the cutter profile for non-standard thread shapes to provide the performance required for a tool and standard tool parameters. For further investigations, spur gears produced by round-ended cutters can be applied symmetrically and asymmetrically.
\end{abstract}

Keywords: AutoLISP, CAD, Complex numbers, Noise analysis, Spur gear

$\ddot{O} z$

Bu çalı̧̧mada, CAD ortamında karmaşık sayılar kullanılarak düz dişlilerin parametrik çizimi ve modellemesi için bir yazılım geliştirilmiştir. Yazılım geliştirmede AutoLISP programlama dili kullanılmıştır. Sistemde modül ve diş sayısı gibi parametreler kullanıcı tarafindan girilerek CAD ortamında dişlilerin çizimi veya modellemesi otomatik olarak yapılabilmektedir. Bu çallşma, tasarımcıya dişli çizimi ve modellemesi için hızl, işlevsel ve daha kesin bir fayda alternatifi sağlamaktadır. Ayrıca çalışma kapsamında klasik yöntemle AutoCAD paket programında aynı sayıda diş ve modülde düz dişli tasarlanmıştır. Geliştirilen paket programı ve klasik yöntemle AutoCAD programında tasarlanan düz dişliler, MasterCAM programında kesme kodları türetilerek tel erozyon makinesinde üretilmiştir. Üretilen düz dişli çiftlerinin gürültü̈ analizi yapılmıştır. Çalışma kapsamında gelişstirilen paket program ile tasarlanan ve üretilen düz dişli çiftinin, klasik yöntemle tasarlanan ve üretilen düz dişliye göre yaklaşık 8 dB daha az gürültü çalıştı̆̆ tespit edilmiştir. Bir takım ve standart takım parametreleri için gerekli performansı sağlamak üzere standart dişı diş şekilleri için kesici profilini değiştirerek dişliyi istenen profilde tasarlamak ve üretmek mümkündür. Daha ileri araştırmalar için, yuvarlak uçlu kesicilerle üretilen düz dişliler simetrik ve asimetrik olarak uygulanabilir.

Anahtar kelimeler: AutoLISP, CAD, Kompleks sayılar, Gürültü analizi, Düz dişli

\footnotetext{
${ }^{* a}$ Mehmet YAZAR; mehmetyazar@ comu.edu.tr, Tel: (0286) 21800 18, orcid.org/0000-0003-3999-3233

${ }^{\mathrm{b}}$ orcid.org/0000-0003-1075-313X
} 


\section{Introduction \\ 1. Giriş}

Since the beginning of the technology, one of the important machine elements is the gear. The designs of the first gears were mostly made using pins (Laczik et al., 2014).

Machine elements designed to transmit force and movement between different parts within a mechanism are gear wheels. The most important point in the gear design is that the tooth geometry is designed with minimum shear stresses in the contact area (Suslin \& Pilla, 2017). To ensure the most efficient circular contact relationship between gear wheels, tooth geometry design is crucial (Kalpakjian \& Schmid, 2006). Researchers have constantly investigated the effects of friction and wear to make a design under optimal operating conditions (Patil et al., 2019) Thanks to the technological developments of the last century, gear wheels have become the machine elements used in almost every machine, and therefore, the calculation of gear wheels are very common in machine manufacturing. For this purpose, it was tried to obtain fast and precise results by adapting the deficiencies encountered to computer environment. It is thought that this will contribute to the faster shaping of the manufacturing process and increase the production capacity. The computer, which is the greatest convenience of today's modern technology, has entered almost all fields. One of the most common areas is machine design. For this reason, computer aided design of machine elements has emerged in order to transfer the necessary data for the design and calculation of machine elements from theory to practice in the easiest way.

Developed in parallel with the rapid advances in computer technology, the software enables many engineering activities to be carried out easily in the computer environment. By simulating the manufacturing process, the effects of many parameters on the product can be examined before manufacturing. Thus, it is possible to make changes during design with minimum cost and time loss (Oladejo \& Ogunsade, 2014). From the studies on spur gear design; on the purpose of create an ideal spur gear profile, an algorithm has been developed and the two-dimensional drawing of the spur gear is realized according to the module, number of teeth and grip angle entered into the developed algorithm (Reyes et al., 2008). In this way, no need for manual technical drawing studies has been provided to increase productivity and reduce costs (Nordiana et al., 2007).
Involute developed a computer aided kinematic model for the design of spur gears and developed an assistive approach to obtain the optimum dimensions of the gears and perform manufacturing, tensile and compression analysis (Karpat et al., 2002). The developed programs were compared with the results of a sample calculation with the calculation results obtained with commercial software and theoretical calculations. As a result, the values closest to the theoretical calculation results were obtained with the computer program developed in the studies (Krishna \& Srinvas, 2012).

A computer program has been developed to minimize the possible calculation errors and time by facilitating the approximate design and finite element analysis of a complex process gear (Yiqiang et al., 2014). In this study, a software which works in AutoCAD environment is developed by using AutoLISP programming language. The developed software aims to simplify the drawing and modeling of gear wheels and gear pairs. Unlike the other studies in the literature, complex numbers were used instead of formulas used in the calculation of classical spur gear design. The complex numbers used are the twodimensional drawing of the flat wheels according to the rolling method, as well as the threedimensional solid modeling of the gear. In addition, the production of spur gear designed with the package program developed within the scope of working with the spur gear designed by classical methods was cut on the wire EDM machine and noise analysis was made.

\section{Materials and methods \\ 2. Gereç ve yöntem}

\subsection{Parametric spur gear applications \\ 2.1. Parametrik düz dişli uygulamaları}

The parametric gear forming system has been developed to support the automatic 2D drawing and 3D modeling of gear types that are not included in the part libraries of contemporary CAD systems, minimizing the easy, fast and user interaction of gear and gear pairs in the CAD environment.

These basic and calculated dimensions were obtained with the help of the developed program and 2-D drawings and 3-D models of gear wheels and gear pairs discussed in the system were created in the CAD environment. 


\subsection{Geometry of involute gear}

\subsection{Evolvent dişli geometrisi}

Involute tooth geometry is used in tooth profiles of flat, helical, bevel gear wheels. When the gear wheel is examined geometrically, it is seen that it consists of a tooth profile, concentric circle springs at the tooth head and base, involute curves on the tooth side surfaces and trochoid curves in the region that connects the tooth side surfaces to the bottom circle (Figure 1).

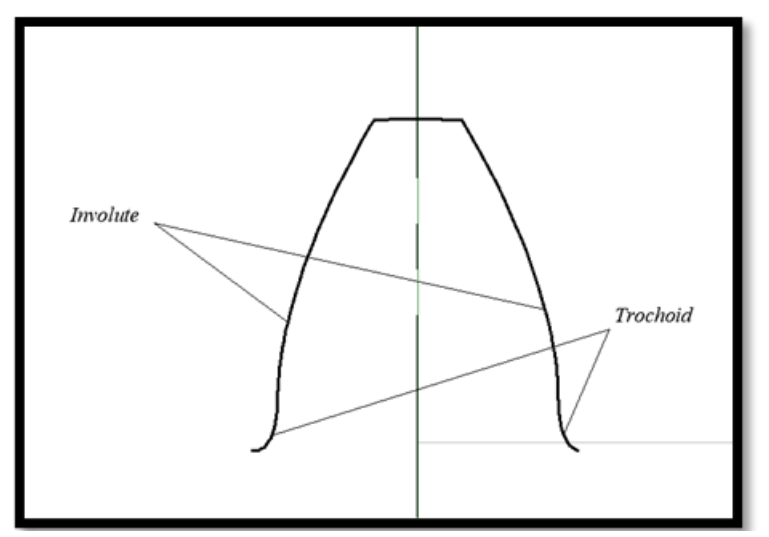

Figure 1. Involute gear geometry

Şekil 1. Elvolvent dişli diş geometrisi

In this study, in order to obtain the involute gear profile, parametric expressions which determined the involute profile developed by Litvin and the tooth base profile in the trochoid form were used (Litvin \& Fuentes, 2004). Involute geometry is shown in Figure 2.

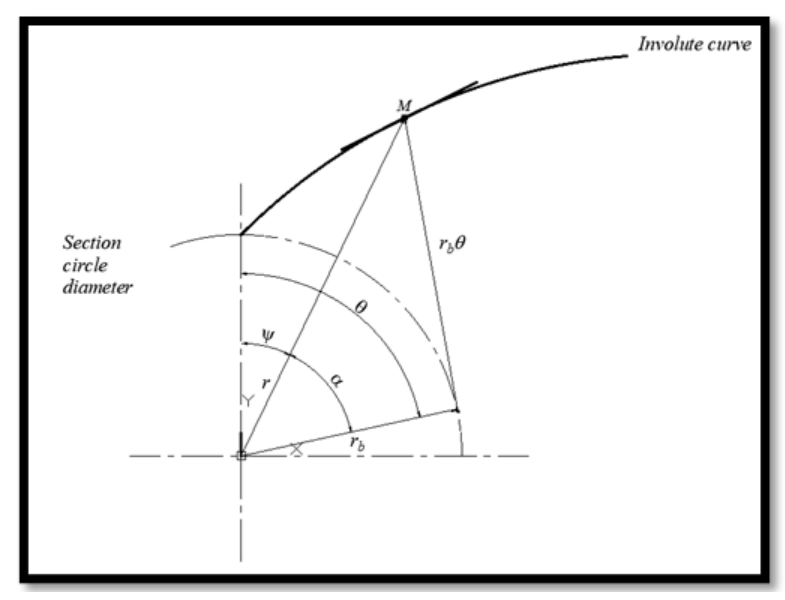

Figure 2. Generating involute profile Şekil 2. Evolvent profilinin oluşumu
Involute angle $\psi$, when the grip angle $\alpha$ is assumed,

$\psi=e v \cdot a=\tan \alpha-a$

available as and the angle of rotation $\theta$ in the involute profile is expressed by the following equation.

$\theta=\psi+a=\tan \alpha$

The parametric expression $M\left(\theta, r_{b}\right)$, which gives the position of a point on the involute profile, is shown as the angle of rotation $\theta$ and the radius of the base circle $r_{b}$ in the involute profile.

$M\left(\theta, r_{b}\right)=\left\{\begin{array}{c}x(\theta)=r_{b}(\sin \theta-\theta \cos \theta) \\ y(\theta)=r_{b}(\cos \theta+\sin \theta)\end{array}\right.$

$\theta_{\max }=\theta_{\alpha}+e v \theta_{\alpha}$ is in the range of $0 \leq \theta \leq \theta_{\text {max }}$, the change interval of the rolling parameter. $\theta_{\alpha}$ the rolling parameter in the tooth head circle is the value of the tooth radius, ra.

$\theta_{\alpha}=\cos ^{-1} \frac{r_{b}}{r_{a}}$

is obtained from the equation. The geometry of the cutting tool that obtains the tooth profile shown in Figure 3 is shown in Figure 5. The position of the center of curvature of the rounded end of the tool, the module $(m)$ the gripping angle $(\alpha)$, the profile shift factor $\left(x_{1}\right)$ and the tool nose rounding radius $(\rho)$, is expressed in the following equation.

$\alpha=\frac{m(\pi-5 \tan \alpha)}{4}-\frac{\rho(1-\sin \alpha)}{\cos \alpha}$

$b=1.25 m-\rho-m x_{1}$

Depending on the tool geometry, the equations representing the tooth-bottom curve in the trochoid form shown in Figure 3, including the angle of rotation, 


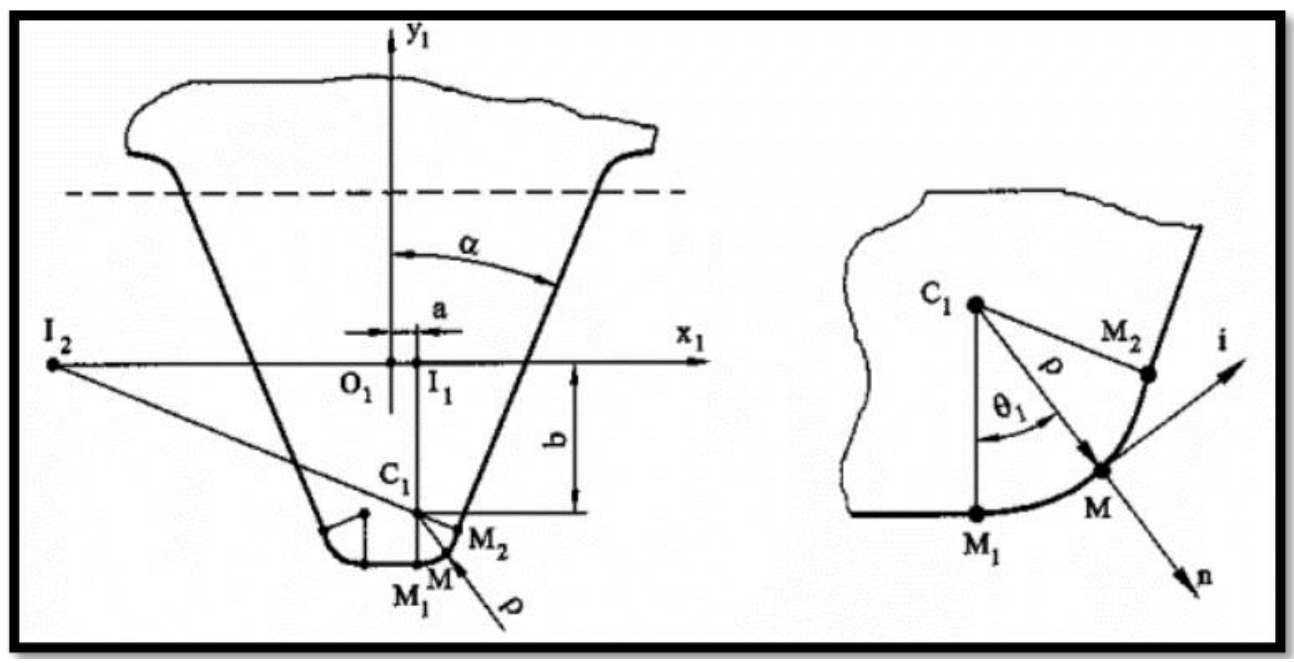

Figure 3. Cutting tool geometry and tool tip detail (Patil et al., 2019)

Şekil 3. Kesici takım geometrisi ve takım ucu detayl (Patil et al., 2019)

$x_{2}=\rho \sin \left(\theta_{1}-\varphi\right)+a \cos \varphi-b \sin \varphi+r(\sin \varphi-\varphi \cos \varphi)$

$y_{2}=\rho \cos \left(\theta_{1}-\varphi\right)-a \sin \varphi-b \cos \varphi+r(\cos \varphi-\varphi \sin \varphi)$

is expressed as. The tool tip spring parameter changes in the range $0 \leq \theta_{1} \leq(\pi / 2)-\alpha$ (5) and (6)

$\phi=\frac{b \tan \left(\theta_{1}-\alpha\right)}{r}$

using the expressions giving the position of the center of curvature of the rounded end of the tool obtained from the equations,

as. The obtained rotation angles are written in place of the equations (7) and (8), and the geometric location of the tooth base curve is found.

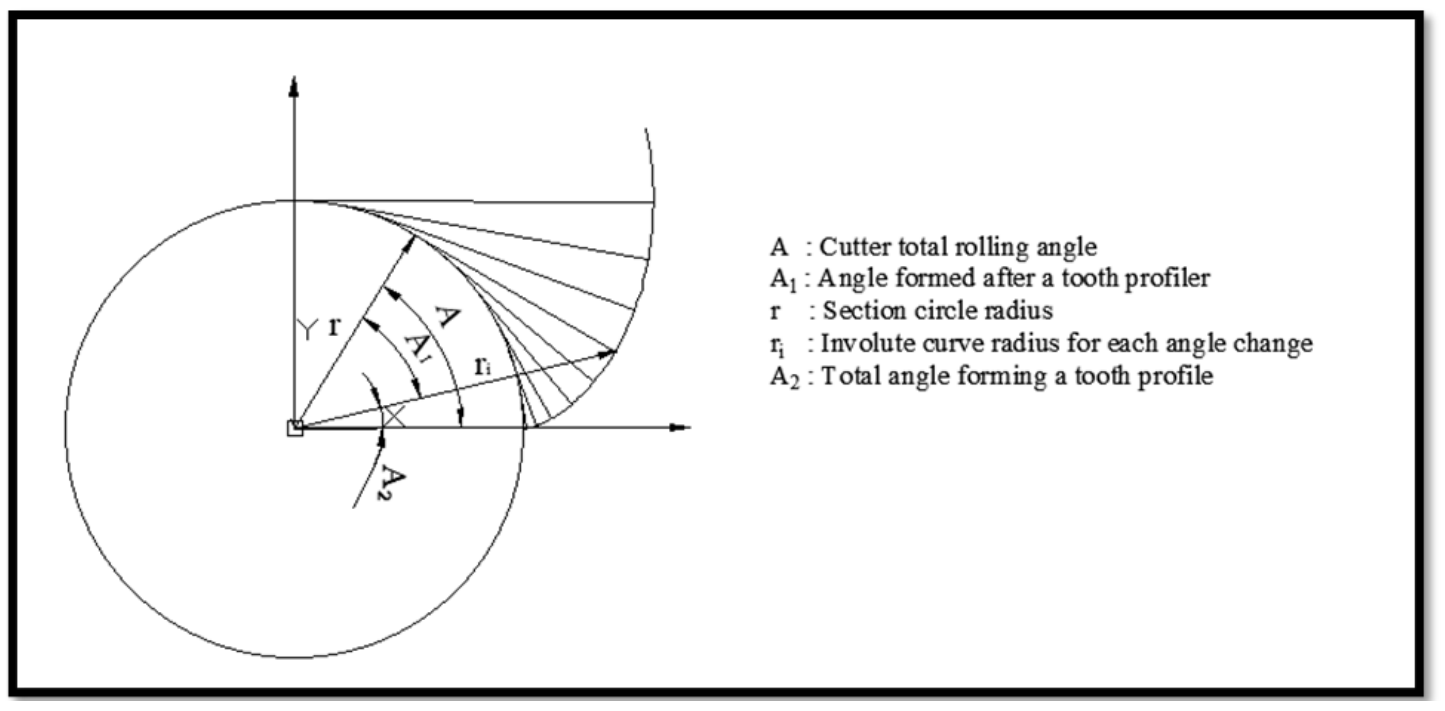

Figure 4. Obtaining the involute of the circle Şekil 4. Dairenin evolventinin elde edilmesi

According to the rolling method, the involute of the circle must be obtained for gear design in AutoCAD environment (Figure 4). Using the $q=\frac{\pi d g}{360}$ following equations, the involute of the circle is obtained.

$r_{i}=\sqrt{r^{2}+q^{2}}$ 
$A_{1}=\tan ^{-1}(q / r)$

$A_{2}=A-A_{1}$

$X=\sin \left(A_{2}\right) r_{i}$

$Y_{1}=\cos \left(A_{2}\right) r_{i}$

$Y=Y_{1}-r$

Involute $=R \beta_{j}+I(R+x m) e^{(I \beta j)}$

Obtaining Circle Involute Using Complex Numbers; A package program was developed using the AutoLISP programming language to obtain the apartment's involute AutoCAD using the equation expressed in complex form 17 . The twodimensional drawing of the involute of an exemplary circle is shown in Figure 5 and Figure 6.

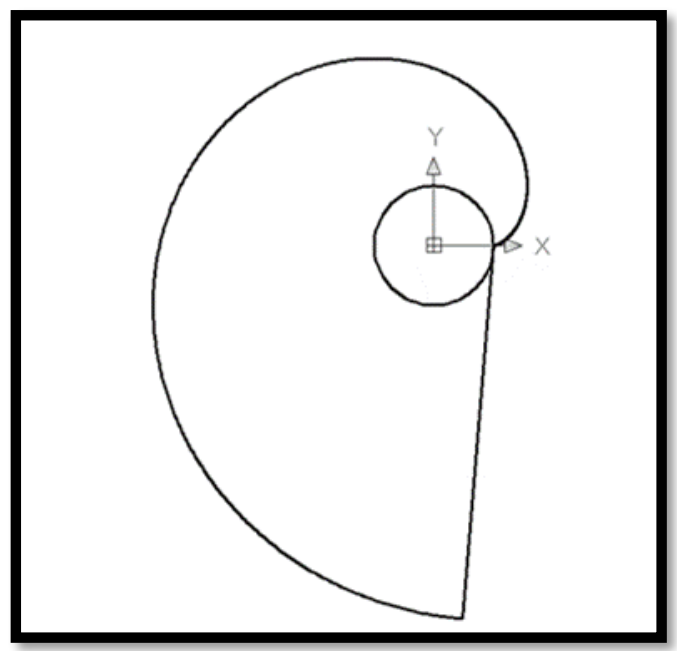

Figure 5. The unilateral involute of the circle Şekil 5. Dairenin tek yönlü evolventi

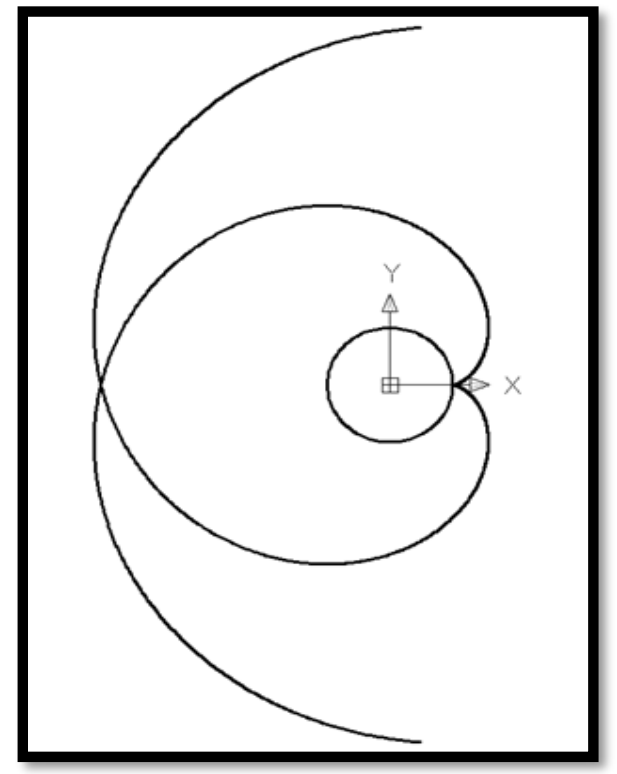

Figure 6. Double-sided involute of the circle Şekil 6. Dairenin çift taraflı evolventi

Obtaining circular spur gear using complex numbers by rolling method; In order to obtain circular gear wheels by rolling method in AutoCAD environment, firstly the cutter profile was obtained by using the equations used to obtain the cutter profile (Figure 7) and the equations used in obtaining the involute of the circle were taken into consideration. The module program developed in AuoLISP programming environment was used to draw the desired number of teeth according to the rounding method and the gear wheel in the module by means of the complex equations formed. An example of a circular gear wheel with two number of teeth 22 and module 2 is performed in AutoCAD environment according to the rolling method with the help of module program developed using AutoLISP programming language is given in Figure 8-10. In addition, the 2D and 3D pictures of the spur gear designed in AutoCAD with the classical method are given in Figure 1112.

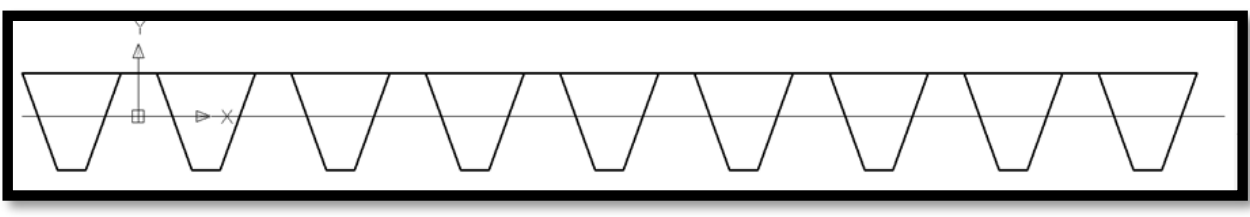

Figure 7. Obtaining the rack cutter profile in AutoCAD environment.

Sekil 7. AutoCAD ortamında kramayer kesicinin elde edilmesi

Lengths $x_{1}$ and $x_{2}$ of the oblique sidewalls of the rack cutter;

$$
x_{1}=-\left(h_{1}+c\right) m \tan (\alpha)+\frac{m \pi}{4}
$$




$$
x_{2}=-\left(h_{2}+c\right) m \tan (\alpha)+\frac{m \pi}{4}
$$

obtained with the equation.

The tooth height $y_{1}$ and $y_{2}$ distances of the rack cutter;

$$
\begin{aligned}
& y_{1}=h_{1} m \\
& y_{2}=\left(h_{2}+c\right) m \\
& \Delta=\frac{m \pi}{2}
\end{aligned}
$$

obtained with the equation.

$x_{1}$ and $x_{2}$ distances to the origin of the oblique cheeks of the rack cutter;

$$
\begin{aligned}
& Q_{0}=x_{1}+I y_{1}-\Delta \\
& Q_{1}=x_{2}-I y_{2}-\Delta
\end{aligned}
$$

obtained with the equation.

The distances $y_{1}$ and $y_{2}$ from the perpendicular sidewalls of the rack cutter;

$$
\begin{aligned}
& Q_{2}=-x_{2}-I y_{2}-\Delta \\
& Q_{3}=-x_{1}+I y_{1}-\Delta
\end{aligned}
$$

obtained with the equation.

Tooth profiles of spur gear according to rounding method;

$$
h_{j, k}=Q_{S}+R \beta_{j}+I(R+x m) e^{(I \beta j)}
$$

obtained with the equation.

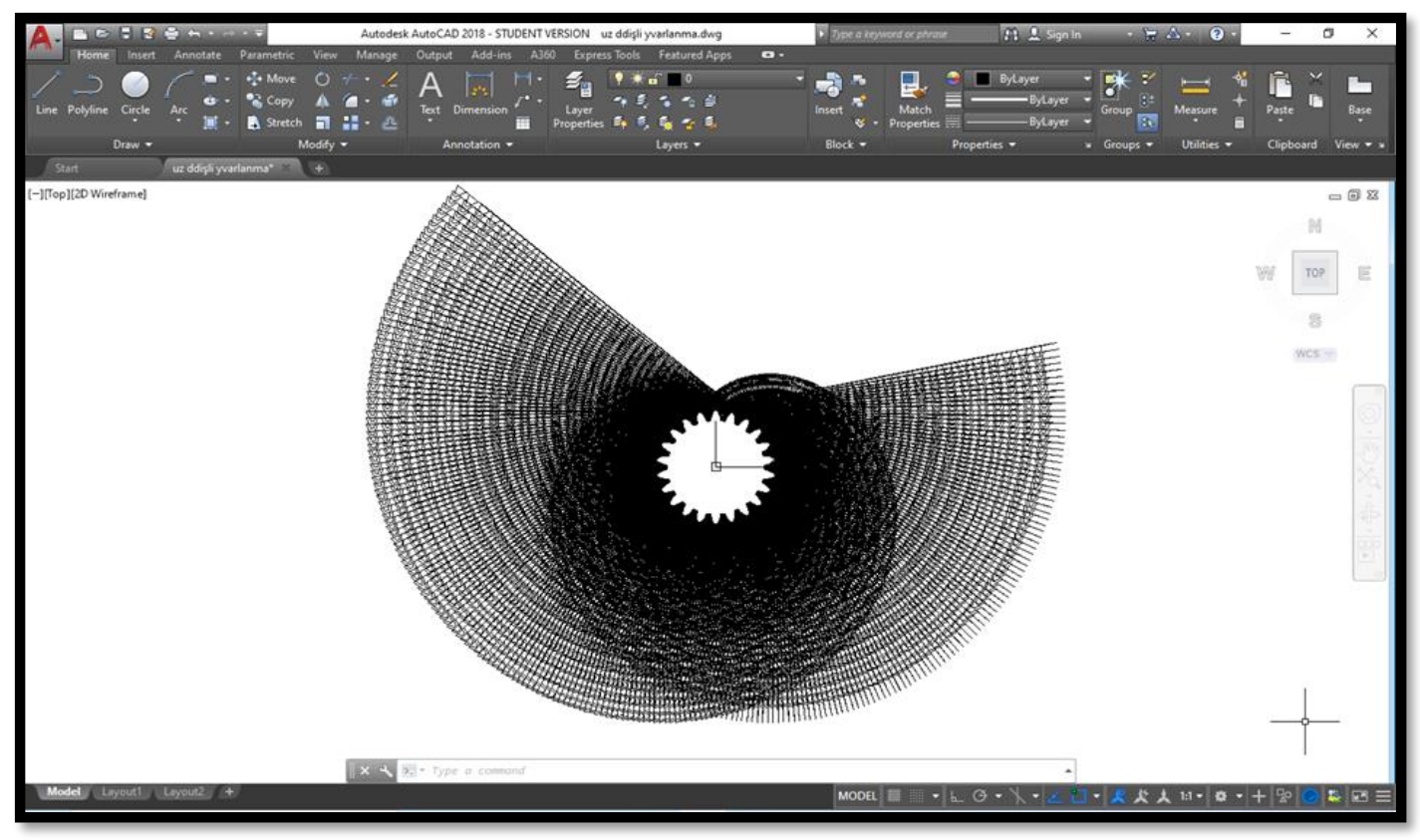

Figure 8. Design of spur gear in AutoCAD according to package programming rolling method developed within the scope of the study

Şekil 8. Çalı̧̧ma kapsamında geliştirilen paket programlama yuvarlama yöntemine göre AutoCAD'de düz dişli tasarımı 


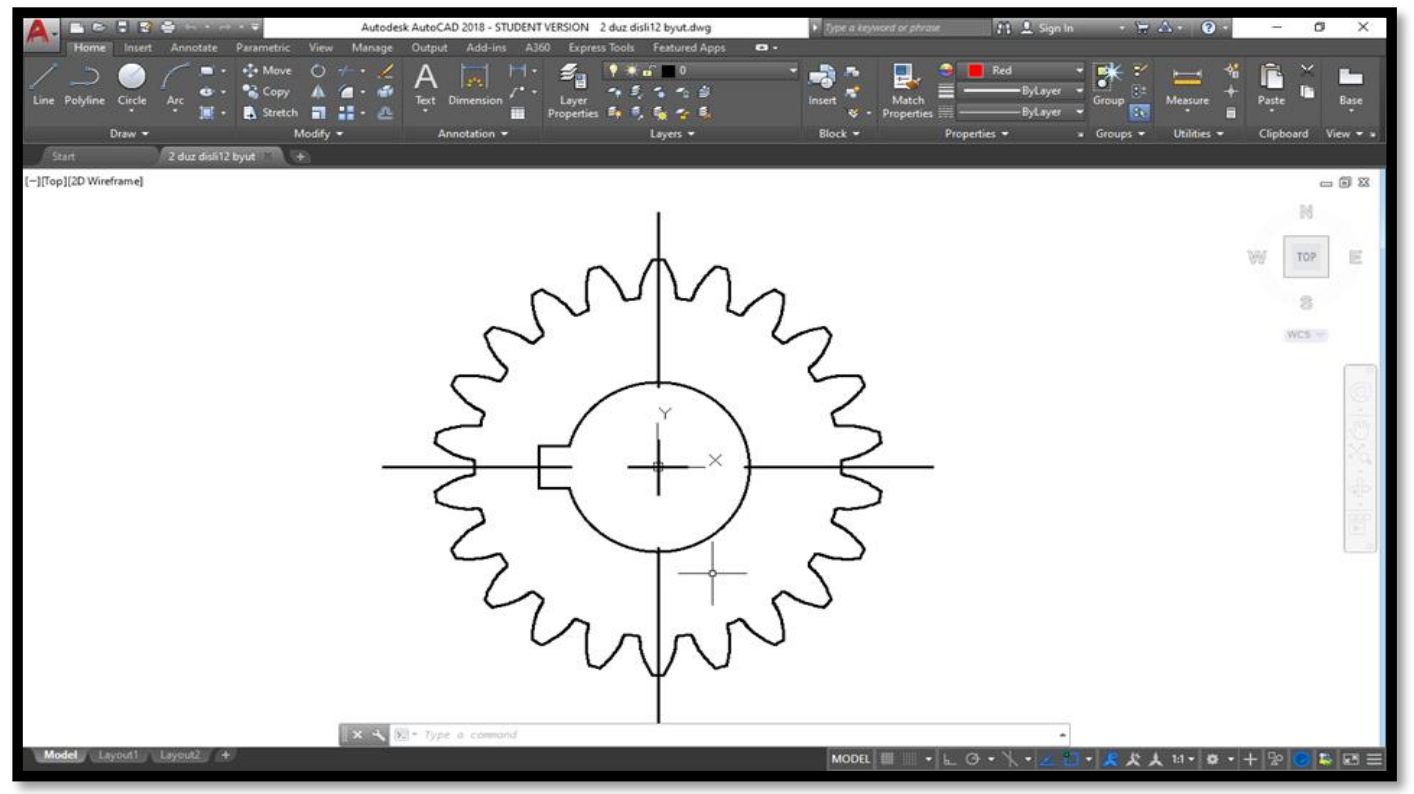

Figure 9. 2D spur gear designed in AutoCAD with the package program developed with AutoLISP programming language within the scope of the study.

Şekil 9. Çalışma kapsamında AutoLISP programlama dili ile geliştirilen paket program ile AutoCAD ortaminda tasarlanan 2 boyutlu düz dişli.

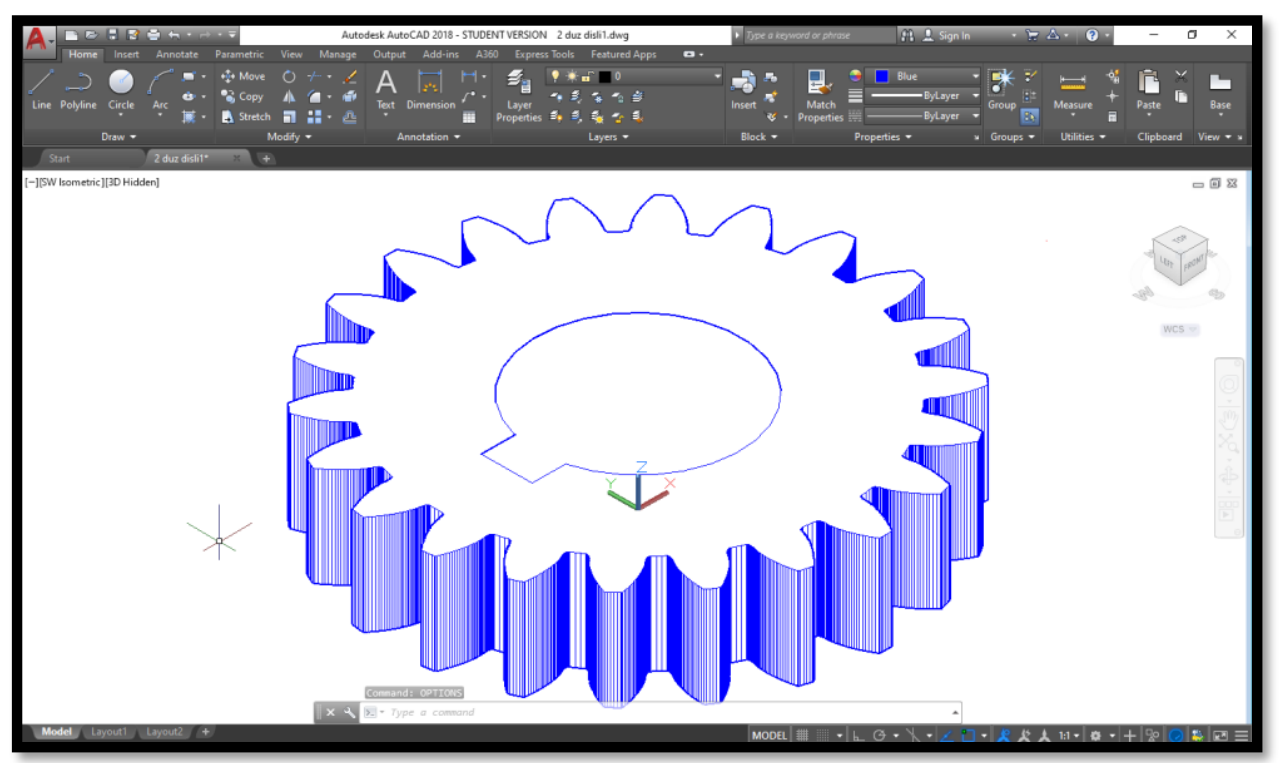

Figure 10. 3D spur gear designed in AutoCAD with the package program developed with AutoLISP programming language within the scope of the study.

Şekil 10. Çalışma kapsamında AutoLISP programlama dili ile geliştirilen paket program ile AutoCAD ortamında tasarlanan 3 boyutlu düz dişli. 


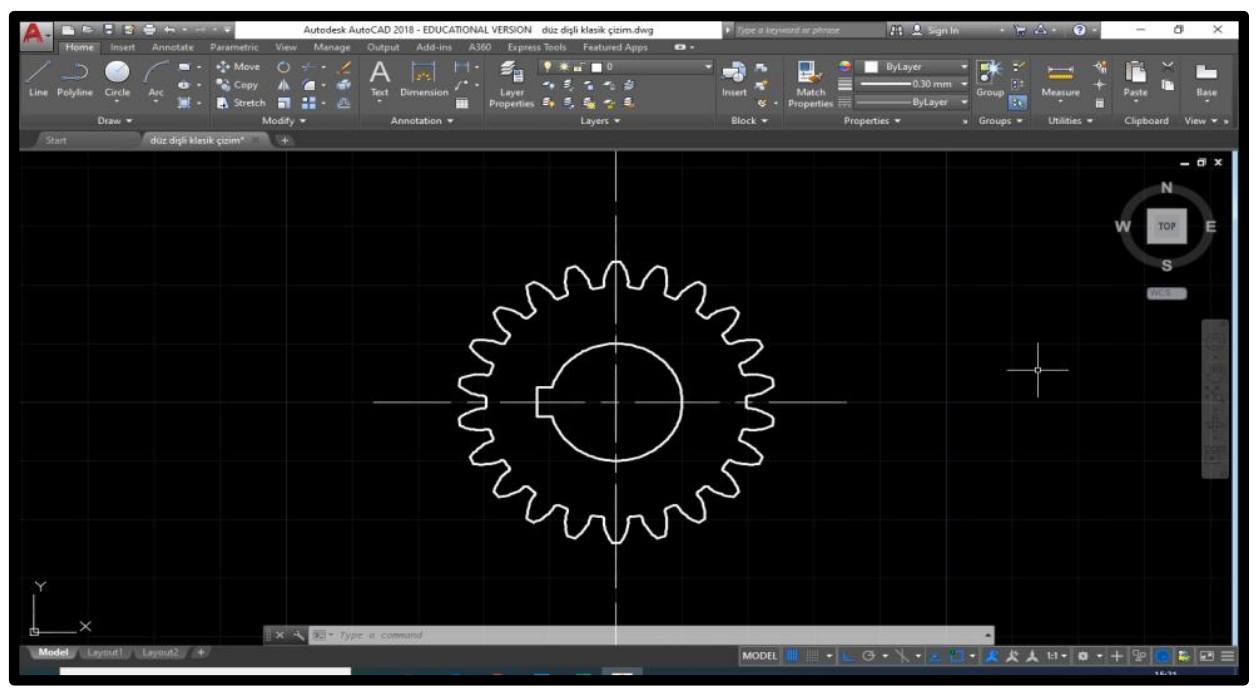

Figure 11. Spur gear designed in 2D with classical method in AutoCAD program. Şekil 11. AutoCAD programında klasik yöntemle 2 boyutlu olarak tasarlanan düz dişli.

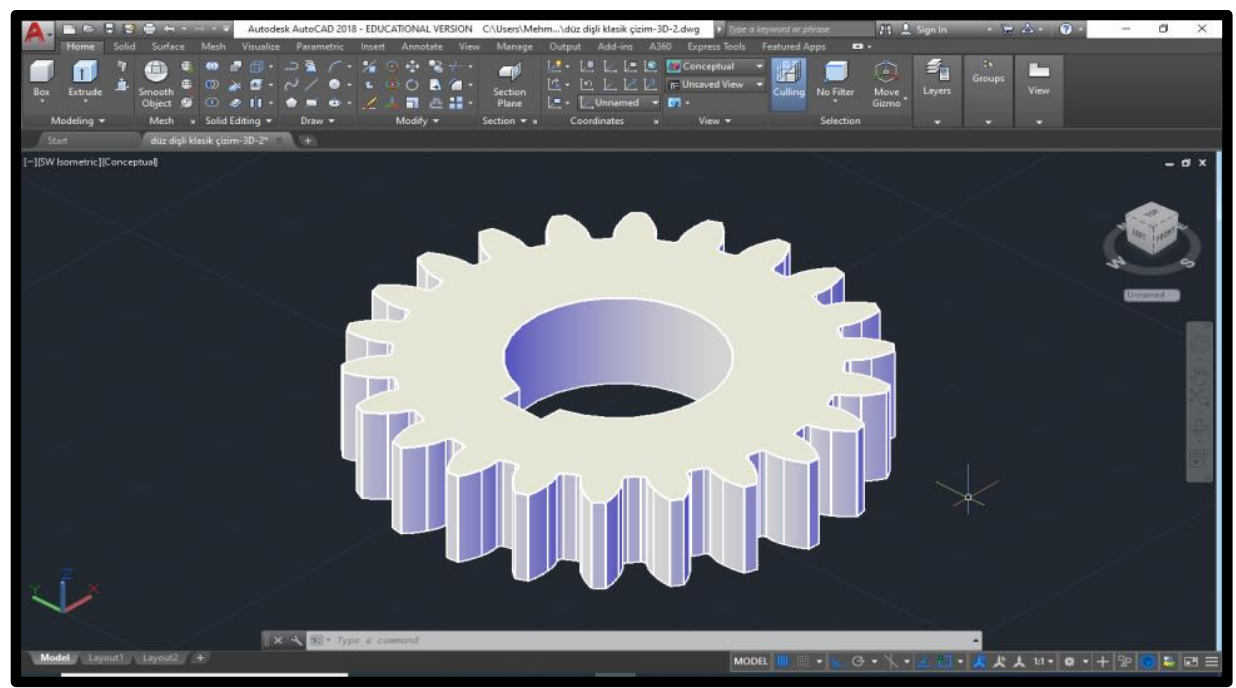

Figure 12. Spur gear designed in 3D with classical method in AutoCAD program Şekil 12. AutoCAD programında klasik yöntemle 3 boyutlu olarak tasarlanan düz dişli

\section{Results}

\section{Bulgular}

3.1. Design and manufacture of spur gears and, test apparatus used in experiments

3.1. Düz dislilerin ve deneylerde kullanılan test cihazının tasarımı ve imalatı

The 2D designs of the gears used in the experiments were made in separately AutoCAD environment both with the classical method and with the package program developed with the AutoLISP programming language within the scope of the study. The parameters of the designed spur gears are given in Table 1.
Table 1. Parameters that belong to spur gears cut for experimental studies

Tablo 1. Deneysel çalışmalar için kesilen düz dişlilere ait parametreler

\begin{tabular}{ll}
\hline \multicolumn{1}{c}{ Supur gear parameters } & \multicolumn{1}{c}{ Value } \\
\hline Number of Teeth & 22 \\
Module & 2 \\
Shaft Angele & $90^{0}$ \\
Pressure Angle & $20^{0}$ \\
Addendum & $2.000 \mathrm{~mm}$ \\
Dedendum & $2.336 \mathrm{~mm}$ \\
Pitch Circle Diameter & $44.000 \mathrm{~mm}$ \\
Face Width & $10.000 \mathrm{~mm}$ \\
Clearance Factor of Depths & 0.250 \\
\hline
\end{tabular}


Table 2. AISI 1050 Chemical compositions (in weight \%)

Tablo 2. AISI 1050 Kimyasal bileşimler (\% ağırlık olarak)

\begin{tabular}{cccccccc}
\hline & C & Si & Mn & Cr & Mo & Ni & Usage Areas \\
\hline AISI 1040 & 0.51 & 0.20 & 0.75 & 0.20 & 0.05 & 0.20 & $\begin{array}{l}\text { Transmission pins, rails, sprockets, etc. } \\
\text { They are used in manufacturing and can } \\
\text { be induction furnace and flame-harden. }\end{array}$ \\
\hline
\end{tabular}

In order for the spur gear pairs to be convenient and reference in experimental studies, $20 \mathrm{~mm}$ diameter cylindrical holes with keyway of $6 \mathrm{~mm}$ width and $3.2 \mathrm{~mm}$ depth were designed in AutoCAD environment and processed in piece size on the wire EDM. Therefore, the axis exceeding through the rotation center of the spur gear wheels and the planes forming the cheeks of the spur gears are provided to be parallel. In addition, the roughness of the tooth surfaces of the gear wheels at the end of cutting was measured to determine the machining quality. The roughness measurement was made on a single tooth surface using the Mahr Perthometer M1 surface roughness measuring device on the gear wheel section circle and the surface roughness value was measured as $2.368 \mathrm{Ra}$ $(\mu \mathrm{a})$.
On the purpose of specify the noise values of the produced spur gear pairs, the analysis apparatus was designed and produced according to its dimensions.

In the analysis apparatus, a grinded plate was placed on the flat stand and the rotating gear wheel shaft was ground on this plate and bedded with a double ball bearing. The rotated spur gear shaft is fixed on the ground plate by bearing double ball bearings. A ground flat table is mounted on four ball linear guides. A movable table was formed by mounting a spur gear shaft rotated on the table. The movable table is mounted on the plate with a spring on both sides. The performance of noise analysis is given in Figure 13.

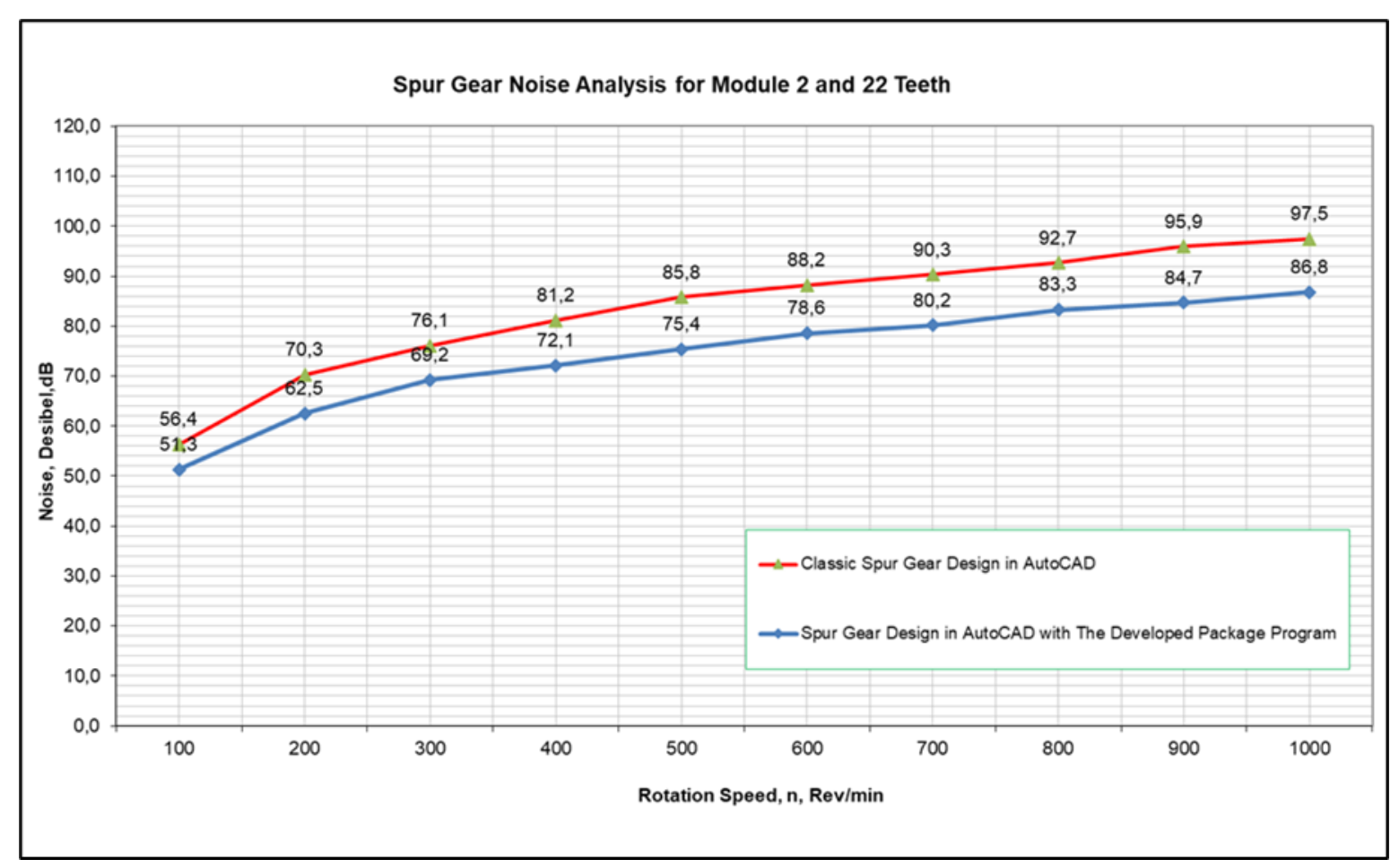

Figure 13. Noise graphic of spur gears

Şekil 13. Düz dişli gürültü grafiği

\subsection{Noise analysis of spur gears}

\subsection{Düz dişli gürültü analizi}

Increasing the rotational speed means increasing the peripheral speed of the gears. As the peripheral speed increases, the noise level of the mechanism increases, and the abrasion increases. Therefore, if working at high speeds, the surface quality of the spur gears should be high. While performing the noise analysis of the gears in the noise analyzer, the speed of the gears was measured with a digital tachometer on the spur gear shaft. DT-2236 Digital 
Photo / Contact Tachometer was used to measure the number of revolutions of gears. The measuring range of the tachometer is $0.5-100.000 \mathrm{rpm}$ and the measurement accuracy is $0.05 \%$. CASELLA CEL231 Digital Sound Level Meter was used to measure the noise level. The measuring range of the appliance is $30-135$ decibels $(\mathrm{dB})$. The speed and noise measurements of the gears were made three times and the arithmetic mean of these three measurement results was taken. The noise values for each number of revolutions were determined. The graph showing the noise values obtained from the measurement results based on the number of revolutions is given in Figure 13. As can be seen from the examination of this graph, it has been observed that the noise value increases with the increase in the number of revolutions and the speed of the spur gears. Also, the noise level of the spur gear pair designed with the package program developed within the scope of the study was determination to be approximately $8 \mathrm{~dB}$ less than the spur gear pair designed with the classical method.

\section{Discussion and conclusion \\ 4. Tartışma ve sonuç}

In literature, mostly homogeneous transformation matrix method is used for gear contact problems in order to solve rotation and rotation problems. In this study, a different approach is presented using complex numbers to design the profiles of gears and tooth profiles. This study demonstrates the applicability of the gear design process with this new method. Within the scope of the study, a software has been developed with AutoLISP programming language for computer aided design and solid modeling of spur gears. With the developed software, 2D drawings and 3D modeling of spur gear can be done automatically according to the input parameters entered by the user. This software can be used effectively to reduce the time spent on manual gear calculations and the transfer of gears to the CAD environment in both 2D and $3 \mathrm{D}$ and to eliminate calculation, drawing and modeling errors. The use of the program developed in this respect is thought to facilitate the 2D design, sizing, and 3D modeling of spur gear in the AutoCAD environment. Also, other spur gear pairs are designed with the classical method in the AutoCAD program. These designed spur gear pairs were produced in the wire EDM. The noise analysis of the produced spur gear pairs was made and the noise value of the spur gear design with the classical method was approximately $8 \mathrm{~dB}$ higher.
- The correct gear design depends on its ability to withstand high friction and high bending stresses at the bottom of the tooth. One of the biggest obstacles that designers face is that the gears are not designed to the required configuration as desired. For spur gears, geometry is boring and time consuming. With this study, instead of the standard approximate size design of spur gears, a package program has been developed with AutoLISP language for gear design at desired dimensions and standards in AutoCAD environment.

- The tooth surface of the spur gear is formed on the basis of the shaping principles of the tooth surfaces according to the involute method. Polar equations and complex numbers are availability to realize this involute method.

- It offers a design package program using special complex numbers to prepare spur gears for special configuration. The user can change design variables at any time to meet any constraints applied. The program is easy to use and can be developed in the design of other gears.

- One of the most important points in gear design is the stresses that occur at the contact points of the gears. These stresses can be reduced by the pointing of the contact surface of the toothed tooth profiles. The complex structure of the tooth profile and the complex manufacturing technology are difficult to design for the manufacture of gears with point contact. However, advances in gear manufacturing technologies have facilitated the production of such gears. These gears will provide better contact strength and vibration characteristics as they will provide point contact compared to gears manufactured with standard design. This study is thought to solve various gear contact problems.

- There are many methods for developing tooth profiles of gears. Most techniques use only the tooth profile with an approximate value. In this study, it is tried to find the desired real values.

- It is possible to design and manufacture the gear in the desired profile by changing the cutter profile for non-standard thread shapes to provide the performance required for a tool and standard tool parameters. 
- Increasing the rotational speed means increasing the circumferential speed of spur gear wheels. With the increase in the peripheral speed, the sound level of the mechanism increases and the abrasion increases. Therefore, research based on surface quality, hardness and wear behavior of spur gear wheels operating at high speeds will be important.

- The material with the lowest sound propagation speed should be chosen as the body material. However, by not forgetting the criteria such as manufacturing method and processing, aluminum alloys can be used frequently as body materials as a material that is easy to cast, light and easily processed. AISI 1040 was used in this study. It will be appropriate to consider in different materials.

- In this study, the grip angle of the spur gear pairs is taken as 200. Choosing a small grip angle slightly increases the grip ratio. The small grip angle reduces the radial forces generated. This can make the mechanism work quieter. The effect of different grip angles will be a separate study.

- Even after a very sensitive project and assembly, a gap remains between the teeth. Since this gap is also necessary for lubrication and shape and displacements may occur during operation, the gap should be anticipated at the design stage.

- From the literature studies done, the factors affecting gear wheel tooth life are lubrication, temperature, speed, material, load, manufacturing precision, assembly precision, geometric dimensions of gears (module, number of teeth, tooth width, etc.), geometry of tooth profiles etc. determined as. Determining how long the life of the gears under which conditions can enable the determination of gear damage in advance and take necessary precautions in advance.

- While the spur gear designed with the package program developed within the scope of the study was designed, the rolling angle of the cutter on the spur gear part circle was set as 1 degree. When this angle value is decreased, it is predicted that the surface quality will increase, and the noise ratio will decrease.

\section{Author contribution \\ Yazar katkısı}

The authors' contribution rates in the study are equal.

\section{Declaration of ethical code Etik beyanı}

The authors of this article declare that the materials and methods used in this study do not require ethical committee approval and/or legal-specific permission.

\section{Conflicts of interest \\ Çıkar çatışması beyanı}

The authors declare that there is no conflict of interest.

\section{References}

Kaynaklar

Kalpakjian, S. \& Schmid, S. R. (2006). Manufacturing Engineering and Technology, $\left(5^{\text {th }}\right.$ ed.). Pearson Education Center

Karpat, F., Çavdar, K. \& Babalık, F. C. (2002). Bilgisayar yardımıla düz, helisel, konik ve sonsuz vida dişli mekanizmalarının boyutlandırılması ve analizi. Mühendis ve Makine Dergisi, 510.

Krishna, G. G. \& Srinvas, K. (2012). Design of involute spur gears with asymmetric teeth and direct gear design. International Journal of Engineering Research, 1(6), 4.

Laczik, B., Zentay, P. \& Horváth, R. (2014). A new approach for designing gear profiles using closed complex equations. Acta Polytechnica Hungarica, 11(6), 159-172.

Litvin, F. L. \& Fuentes, A. (2004). Gear Geometry and Applied Theory. $\left(2^{\text {nd }} \quad\right.$ ed.). Cambridge: Cambridge University Press.

Nordiana, J. O., Ogbeide, S. O., Ehigiamusoe, N. N. \& Anyasi, F. I. (2007). Computer aided design of a spur gear. Journal of Engineering and Applied Sciences, 2(12), 1743-1747.

Oladejo, K. A. \& Ogunsade, A. A. (2014). Drafting of involute spur-gears in AutoCAD-VBA customized. Advancement in Sciences and Technology Research, 1(2), 18-26.

Patil, S. S., Karuppanan, S. \& Atanasovska, I. (2019). A short review on frictional contact stress distribution in involute gears. Tribology in 
Industry, $\quad 41(2), \quad 254-266$. https://doi.org/10.24874/ti.2019.41.02.11

Reyes, O., Rebolledo, A. \& Sanchez, G. (2008). Algorithm to describe the ideal spur gear profile. Proceedings of the World Congress on Engineering, 2(1), 978-988.

Suslin, A. \& Pilla, C. (2017). Study of Loading in PointInvolute Gears. Procedia Engineering, 176, 1218. https://doi.org/10.1016/j.proeng.2017.02.267.
Yiqiang, J., Li, H., Zhijun, S. \& Huajun, X. (2014). Meshing features of involute arc teeth cylindrical gears. Journal of Chemical and Pharmaceutical Research, 6(7), 2387- 2393.

Zhao, X. \& Vacca, A. (2017). Formulation and optimization of involute spur gear in external gear pump. Mechanism and Machine Theory, 117, 114-132. https://doi.org/10.1016/j.mechmachtheory.2017. 06.020. 